Article

\title{
The Role of Condensed Tannins in the In Vitro Rumen Fermentation Kinetics in Ruminant Species: Feeding Type Involved?
}

\author{
Ives C. S. Bueno ${ }^{1}$, Roberta A. Brandi ${ }^{1}$, Gisele M. Fagundes ${ }^{2, *}$, , Gabriela Benetel ${ }^{1}$ and \\ James Pierre Muir ${ }^{3}$ \\ 1 Department of Animal Science, University of São Paulo, Pirassununga, São Paulo 1365-900, Brazil; \\ ivesbueno@usp.br (I.C.S.B.); robertabrandi@usp.br (R.A.B.); gabriela.benetel@usp.br (G.B.) \\ 2 Department of Animal Science, Federal University of Roraima-UFRR, BR 174, km 12, Boa Vista, \\ Roraima 69300-000, Brazil \\ 3 Texas A\&M AgriLife Research, Texas A\&M University, Stephenville, TX 76401, USA; Jim.Muir@ag.tamu.edu \\ * Correspondence: gisele.fagundes@ufrr.br; Tel.: +55-95-3627-2898
}

Received: 20 February 2020; Accepted: 26 March 2020; Published: 7 April 2020

check for updates

Simple Summary: Inoculum from different feeding types of the ruminant species host has unequal tolerance and effects to condensed tannin (CT) due to their respective feeding strategies behavior producing different ruminal microbiota profiles. This paper describes that in long term incubation, $\mathrm{CT}$ plant extract addition affects in vitro fermentation kinetics more severely in grazing ruminant than browsing ruminants.

\begin{abstract}
Animal feeding behavior and diet composition determine rumen fermentation responses and its microbial characteristics. This study aimed to evaluate the rumen fermentation kinetics of domestic ruminants feeding diets with or without condensed tannins (CT). Holstein dairy cows, Nelore beef cattle, Mediterranean water buffalo, Santa Inês sheep and Saanen goats were used as inoculum donors (three animals of each species). The substrates were maize silage (Zea mays), fresh elephant grass (Pennisetum purpureum), Tifton-85 hay (Cynodon spp.) and fresh alfalfa (Medicago sativa). Acacia (Acacia molissima) extract was used as the external CT source. The in vitro semi-automated gas production technique was used to assess the fermentation kinetics. The experimental design was completely randomized with five inoculum sources (animal species), four substrates (feeds) and two treatments (with or without extract). The inclusion of CT caused more severe effects in grazing ruminants than selector ruminants.
\end{abstract}

Keywords: condensed tannins; fermentability; gas production; grazing ecology; ruminant; microbial responses

\section{Introduction}

Tropical shrubs and trees are important feed for livestock because they are sources of protein [1], minerals and vitamins as well as playing important roles in ruminant feeding systems. However, many of these plant species have secondary compounds capable of changing the utilization of nutrients by mammalian herbivores.

Because plants developed defense mechanisms against herbivores and pathogens, animals have developed mechanisms to nullify or restrict the toxic and negative effects of ingested plant secondary compounds such as condensed tannins (CT) [2,3]. Ruminant herbivores and plant CT coexist and adapt natural evolutionary processes. Some ruminant feeders, especially goats, developed physiological adaptations, and even dependence on CT-rich legumes, selectively including such plants in their 
selector habits [4]. In the case of some browsers such as goats, this adaptation takes the form of salivary glands that produce large amounts of mucus-containing enzymes that can bind to CT to increase palatability and leaving plant proteins more available for digestion [5].

The evolution of different feeding strategies among domestic ruminant species implies differing microbial interactions with $\mathrm{CT}$ and, consequently, the diversity of rumen microorganisms and digestive capacity. Thus, we hypothesize that the role of CT on ruminal fermentability may vary depending on the species of the ruminant and, in the case of in vitro fermentation, the species of the rumen fluid donor. Comparative studies with different rumen-fluid donor species with previous pre-adapted to tannin feeding have been published [6-9]. However, the ability of the rumen microbes of different non-CT-adapted ruminant species to adapt to CT has not been fully investigated. Therefore, the objective of our study was to compare the effects of plant extracts containing CT on ruminal fermentation kinetics of taurine dairy cattle (Bos taurus taurus), zebu beef cattle (Bos taurus indicus), water buffaloes (Bubalus bubalis), sheep (Ovis aries) and goats (Capra hircus) without previous CT feeding exposure.

\section{Material and Methods}

\subsection{Animals}

Rumen fluid donors included three Holstein dairy cows (B. taurus taurus), three Nelore beef cows (B. taurus indicus), three Mediterranean water buffalo cows, three Santa Inês ewes and three Saanen goats. Diets were formulated to meet the nutritional requirements of each animal species/breed and consisted of $60 \%$ to $80 \%$ forage and $20 \%$ to $40 \%$ concentrate with ground maize and soybean meal. All animals were allowed free access to water and mineral mixture. All methods and animal care were performed in accordance with the relevant guidelines and regulations of the Ethic Committee on Animal Use of the School of Animal Science and Food Engineering, (São Paulo University).

\subsection{Substrates}

Four forages were evaluated as substrates: maize silage (Zea mays), fresh elephant grass (Pennisetum purpureum), Tifton-85 hay (Cynodon spp.) and fresh alfalfa (Medicago sativa). Forage samples were dried at $55{ }^{\circ} \mathrm{C}$ and ground through a 1-mm sieve. All were analyzed (Table 1) for dry matter $(\mathrm{DM})$, mineral matter $(\mathrm{MM})$, crude protein $(\mathrm{CP})$ and acid-detergent fiber (ADF) with residual ash according to AOAC [10]. Neutral-detergent fiber (NDF) was estimated according to the methodology described by Mertens [11]. Total phenol (TP) concentrations were determined by the Folin-Ciocalteau reagent method [12] and total tannins (TT) were estimated as the difference in TP concentration before and after the treatment with insoluble polyvinylpolypirrolidone [13], using tannic acid as standard. Condensed tannin concentrations were determined by the butanol- $\mathrm{HCl}$ method [12], using leucocyanidin as a standard.

Table 1. Chemical composition of substrates used during the assay of in vitro fermentation kinetics.

\begin{tabular}{cccccc}
\hline \multirow{2}{*}{ Composition } & \multicolumn{5}{c}{ Substrates $^{(1)}$} \\
\cline { 2 - 6 } & ALF & ELE & TIF & SIL & ACA \\
\hline organic matter $^{(2)}$ & 916.82 & 897.75 & 936.45 & 964.64 & 978.86 \\
ether extract $^{(2)}$ & 84.04 & 46.72 & 57.92 & 62.98 & n.d. $^{(5)}$ \\
crude protein $^{(2)}$ & 278.97 & 60.28 & 158.02 & 82.02 & n.d. $^{(5)}$ \\
neutral-detergent fiber $^{(2)}$ & 735.62 & 770.03 & 795.29 & 563.28 & n.d. $^{(5)}$ \\
acid-detergent fiber $^{(2)}$ & 510.25 & 519.52 & 428.92 & 332.30 & n.d. $^{(5)}$ \\
acid-detergent lignin $^{(2)}$ & 126.69 & 121.63 & 133.08 & 71.35 & n.d. $^{(5)}$ \\
total phenols (3) $^{(3)}$ & 13.60 & 5.47 & 5.32 & 10.18 & 558.63 \\
total tannins $^{(3)}$ & 8.14 & 3.05 & 2.82 & 6.58 & 519.58 \\
condensed tannins $^{(4)}$ & 0.25 & 0.10 & 0.10 & 0.15 & 235.87 \\
\hline
\end{tabular}

(1) ALF: fresh alfalfa; ELE: fresh elephant grass; TIF: Tifton-85 hay; SIL: maize silage; ACA: Acacia tannin extract. (2) expressed as g/kg DM. ${ }^{(3)}$ expressed as eq-g tannic acid/kg DM. ${ }^{\left({ }^{2}\right)}$ expressed as eq-g leucocyanidin $/ \mathrm{kg}$ DM. ${ }^{(5)}$ n.d.: not determined. 
Acacia (Acacia molissima) extract (Seta ${ }^{\circledR}$ Estância Velha, Brazil) was added to the diets to raise the $\mathrm{CT}$ concentration to 50 eq-g of leucocyanidin per $\mathrm{kg}$ of feed DM. This $\mathrm{CT}$ concentration has been appointed as the minimum to cause harmful effects to ruminants [14]. The chemical characterization of substrates and Acacia extract were performed at the Laboratory of Animal Nutrition, Center for Nuclear Energy in Agriculture, University of São Paulo.

\subsection{In Vitro Gas Production Assay}

Ruminal contents were collected through permanent ruminal cannulas from each animal. Equal volumes of liquid and solid phases sample were homogenized in a blender for $10 \mathrm{~s}$. The resulting material was filtered through three layers of cotton (cheese cloth) tissue [15]. Filtered fractions were kept in a water bath at $39^{\circ} \mathrm{C}$ and $\mathrm{CO}_{2}$ saturation until introduced into the in vitro system.

The in vitro gas production described by Theodorou et al. [16] and Maurício et al. [17] was used to compare disappearance rates. Each $160-\mathrm{mL}$ fermentation flask received $0.5 \mathrm{~g}$ of the substrate with or without $0.3 \mathrm{~g}$ of extract CT. The inoculation was performed by injecting $10 \mathrm{~mL}$ of inoculum in $90 \mathrm{~mL}$ of buffered mineral solution [16] into each fermentation flask. The flasks were sealed with rubber stoppers, then shaken and incubated in an oven with forced-air circulation at $39^{\circ} \mathrm{C}$, thus allowing gas accumulation within each flask.

The pressure of the generated gases was measured at 4, 8, 12, 16, 24, 30, 46, 59, 72 and $96 \mathrm{~h}$ after inoculation, using a "transducer" (PressData $800^{\circledR}$ ). After each measuring, the accumulated gas was released from all bottles. These values were used to calculate the volume of gas produced. At the end of this bioassay $(96 \mathrm{~h}), 2 \mathrm{~mL}$ of liquid phase were sampled with a syringe and frozen until analysis of short-chain fatty acids (SCFA). After $96 \mathrm{~h}$, residual material was filtered through sintered crucibles to determine in vitro dry matter degradability (IVDMD) and in vitro organic matter degradability (IVOMD). The partitioning factor (PF), calculated by relating DM degradation and OM degradation to total gas production, was used to compare microbial efficiency [18].

Gas production data were used to determine fermentation kinetics based on the model of Ørskov and McDonald [19] modified by McDonald [20] as:

$$
\begin{gathered}
p=0 \text { to } t<t_{0} \\
p=a+b\left(1-\exp ^{-c t}\right) \text { to } t \geq t_{0}
\end{gathered}
$$

where $p$ is gas production $(\mathrm{ml})$ in time $t ; a$ and $b$ are constants of the model; $c$ is the gas production rate $\left(\mathrm{h}^{-1}\right) ; a+b$ is the potential gas production $(\mathrm{mL}) ; t_{0}$ is the lag time $(\mathrm{h})$.

\subsection{Short-Chain Fatty Acids Determination}

Short-chain fatty acid analysis was measured by gas chromatography (GC-2014, Shimadzu ${ }^{\circledR}$, Tokyo, Japan), split-injector, flame ionization detector and capillary column (Stabilwax ${ }^{\circledR}$, Restek, Bellefonte, PA, USA) at $145^{\circ} \mathrm{C}$ (isothermal) according to Erwin et al. (1961) [21], with adaptations by Getachew et al. [22]. Acetic, propionic, isobutyric, butyric, isovaleric and valeric acid $(99.5 \%$ purity, Chem service, USA) were used as a quantitative external standard. The operational conditions were: injector and detector temperatures were $250{ }^{\circ} \mathrm{C}$; helium was the carrier gas at $8.01 \mathrm{~mL} / \mathrm{min}$; hydrogen flow to the flame jet at $60 \mathrm{kPa}$ and synthetic air at $40 \mathrm{kPa}$. The samples were thawed at room temperature and centrifuged at $14,500 \times g$ for $10 \mathrm{~min}$. The supernatant $(800 \mu \mathrm{L})$ was transferred to a dry and clean flask with $200 \mu \mathrm{L}$ formic acid (98-100\%) and $100 \mu \mathrm{L}$ of the internal standard $(100 \mathrm{mM}$ 2-ethyl butyric acid, Chem service, USA).

\subsection{Experimental Design and Statistical Analysis}

The experiment tested three factors and their interactions. These included four forage substrates, five sources of inoculum (animal species) and two levels of CT extract. Individuals $(n=3)$ of each species constituted the experimental units for three replications. 
The statistical design was completely randomized, according to the following model:

$$
\mathrm{Y}_{\mathrm{ijk}}=\mu+\mathrm{F}_{\mathrm{i}}+\mathrm{S}_{\mathrm{j}}+\mathrm{T}_{\mathrm{k}}+\left(\mathrm{F}_{\mathrm{i}} \times \mathrm{S}_{\mathrm{j}}\right)+\left(\mathrm{S}_{\mathrm{j}} \times \mathrm{T}_{\mathrm{k}}\right)+\left(\mathrm{F}_{\mathrm{i}} \times \mathrm{T}_{\mathrm{k}}\right)+\mathrm{e}_{\mathrm{ijk}}
$$

where $Y_{\mathrm{ijk}}$ is the dependent variable; $\mu$ the overall mean; $\mathrm{F}$ the effect of feeds (substrates) ( $\mathrm{i}=1$ to 4 ); $\mathrm{S}$ the effect of animal species ( $j=1$ to 5$)$; T the effect of $C T(k=1$ to 2$) ; F \times S$ the interaction of feeds and animal species; $\mathrm{S} \times \mathrm{T}$ the interaction of animal species and $\mathrm{CT} ; \mathrm{F} \times \mathrm{T}$ the interaction of feeds and $\mathrm{CT} ; \mathrm{e}_{\mathrm{ijk}}$ the residual error of the model. Results were compared by a Tukey test, using the software SAS for Windows ${ }^{\circledR}$ [23]. Results were considered different at $p \leq 0.05$.

\section{Results}

\subsection{Tannin Extract Effects}

There was an effect $(p \leq 0.001)$ of CT inclusion on IVDMD and IVOMD regardless of the rumen fluid source. The inclusion of CT inhibited fermentation as indicated by the model parameters (Table 2), visualized in Figure 1. The partitioning factor is a measure created to bring together two variables: degradability and gas production. It was greater $(p \leq 0.001)$ when CTs were included in the diet (Table 2).

Table 2. Effect of condensed tannins (CT) on degradability, fermentability and microbial efficiency during in vitro rumen fermentation in four ruminant species.

\begin{tabular}{ccccc}
\hline Variables & no CT & CT & SEM $^{(1)}$ & $p$-Value \\
\hline in vitro DM degradability & $0.646^{\mathrm{a}}$ & $0.466^{\mathrm{b}}$ & 0.0090 & $* * *$ \\
in vitro OM degradability & $0.644^{\mathrm{a}}$ & $0.458^{\mathrm{b}}$ & 0.0095 & $* * *$ \\
partitioning factor (mg DMD/mL) & $3.40^{\mathrm{b}}$ & $7.68^{\mathrm{a}}$ & 0.234 & $* * *$ \\
partitioning factor (mg OMD/mL) & $3.14^{\mathrm{b}}$ & $6.94^{\mathrm{a}}$ & 0.206 & $* * *$ \\
Model parameters (3) & & & & \\
$\mathrm{a}$ & $-27.39^{\mathrm{b}}$ & $-9.06^{\mathrm{a}}$ & 0.816 & $* * *$ \\
$\mathrm{~b}$ & $281.89^{\mathrm{a}}$ & $133.47^{\mathrm{b}}$ & 7.023 & $* * *$ \\
$\mathrm{c}$ & 0.0281 & 0.0258 & 0.00130 & $\mathrm{~ns}$ \\
$\mathrm{a}+\mathrm{b}$ & $254.50^{\mathrm{a}}$ & $124.40^{\mathrm{b}}$ & 7.097 & $* * *$ \\
$\mathrm{t}_{0}$ & $4.39^{\mathrm{a}}$ & $3.06^{\mathrm{b}}$ & 0.149 & $* * *$ \\
\hline
\end{tabular}

(1) SEM: standard error of means. ${ }^{(2)}$ ns: not significant $(p>0.05) ;{ }^{*}: p \leq 0.05 ;{ }^{* *}: p \leq 0.01{ }^{* * * *}: p \leq 0.001 .{ }^{(3)}$ Model of Ørskov and McDonald (1979), modified by McDonald (1981): $p=a+b\left(1-\exp ^{-c t}\right)$, where $p=$ gas production (mL), in time $t ; a$ and $b=$ constants of model; $c=$ production gas rate $\left(\mathrm{h}^{-1}\right) ; a+b=$ potential gas production $(\mathrm{mL}) ; t_{0}=\operatorname{lag}$ time (h) ${ }^{\mathrm{a}, \mathrm{b}}$ means followed by distinct superscripts, within rows, are different (Tukey test at $p \leq 0.05$ ).

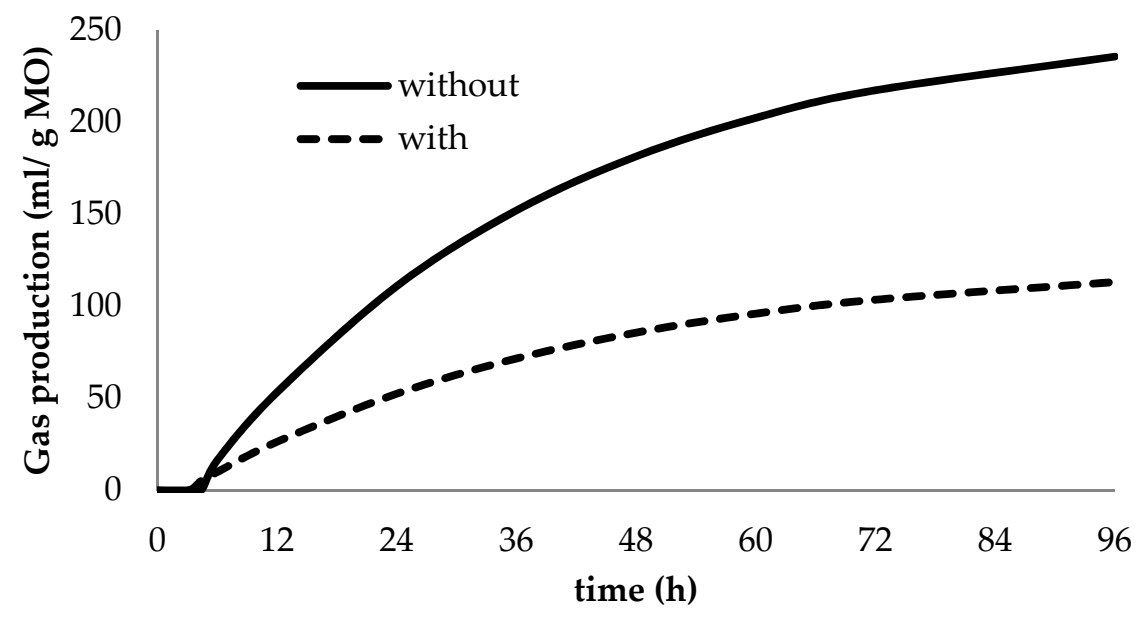

Figure 1. Effects of condensed tannin in diet (with and without) on gas production profiles during in vitro rumen fermentation (pooled over ruminant species). 
Short-chain fatty acids production was also affected by the inclusion of CT extracts (Table 3). The addition of CT promoted a greater $(p \leq 0.001)$ proportion of propionic acid and less $(p \leq 0.001)$ acetic acid.

Table 3. Effect of tannins on short-chain fatty acids (SCFA) production, evaluated during in vitro organic matter rumen fermentation with and without condensed tannins (CT).

\begin{tabular}{ccccc}
\hline Variables & no CT & CT & SEM $^{(1)}$ & $p$-Value \\
\hline \multicolumn{5}{c}{ SCFA production (mmol/g OMD) } \\
\hline acetic acid & $6.57^{\mathrm{a}}$ & $2.83^{\mathrm{b}}$ & 0.26 & $* * * *$ \\
propionic acid & $2.46^{\mathrm{a}}$ & $1.30^{\mathrm{b}}$ & 0.09 & $* * *$ \\
iso-butyric acid & $0.11^{\mathrm{a}}$ & $0.02^{\mathrm{b}}$ & 0.01 & $* * *$ \\
butyric acid & $1.07^{\mathrm{a}}$ & $0.42^{\mathrm{b}}$ & 0.04 & $* * *$ \\
iso-valeric acid & $0.15^{\mathrm{a}}$ & $0.05^{\mathrm{b}}$ & 0.01 & $* * *$ \\
valeric acid & $0.19^{\mathrm{a}}$ & $0.10^{\mathrm{b}}$ & 0.01 & $* * *$ \\
total SCFA & $10.51^{\mathrm{a}}$ & $4.69^{\mathrm{b}}$ & 0.39 & $* * *$
\end{tabular}

(1) SEM: standard error of means. ${ }^{(2)}$ ns: not significant $(p>0.05) ;{ }^{*}: p \leq 0.05 ; * *: p \leq 0.01 ;{ }^{* * *}: p \leq 0.001 .{ }^{\mathrm{a}}, \mathrm{b}$ means followed by distinct superscripts, within rows, are different (Tukey test at $p \leq 0.05$ ).

\subsection{Animal Species Effects}

At the end of the 96-h in vitro fermentation, no differences $(p>0.05)$ in degradability and partitioning factor were observed among animals (Table 4). All species degraded similar proportions of feeds (IVDMD and IVOMD from 0.54 to 0.56 ) with similar microbial efficiency (PF). However, differences $(p \leq 0.01)$ among model parameters were observed (Figure 2$)$. The production of acetic, propionic and butyric acids by each unit of the degraded substrate was greater $(p \leq 0.001)$ in large than in small ruminants and this was reflected in the total amount of SCFA produced (Table 5). Acetate and butyrate to total acid production were not different.

Table 4. Effect of animal species on degradability, fermentability and microbial efficiency assayed in four forages during in vitro rumen fermentation.

\begin{tabular}{|c|c|c|c|c|c|c|c|}
\hline \multirow{2}{*}{ Variable $^{(1)}$} & \multicolumn{5}{|c|}{ Animal Species ${ }^{(2)}$} & \multirow{2}{*}{ SEM $^{(3)}$} & \multirow{2}{*}{$p$ Value ${ }^{(4)}$} \\
\hline & Goats & Sheep & Buffalo & Taurine Cattle & Zebu Cattle & & \\
\hline IVDMD & 0.556 & 0.565 & 0.543 & 0.564 & 0.554 & 0.014 & Ns \\
\hline IVOMD & 0.551 & 0.560 & 0.538 & 0.559 & 0.547 & 0.015 & Ns \\
\hline $\begin{array}{c}\mathrm{PF}(\mathrm{mg} \\
\mathrm{DMD} / \mathrm{mL})\end{array}$ & 5.15 & 4.94 & 6.19 & 5.70 & 5.69 & 0.37 & Ns \\
\hline $\begin{array}{c}\mathrm{PF}(\mathrm{mg} \\
\mathrm{OMD} / \mathrm{mL})\end{array}$ & 4.65 & 4.48 & 5.70 & 5.31 & 5.07 & 0.33 & Ns \\
\hline \multicolumn{8}{|c|}{ Model parameters ${ }^{(5)}$} \\
\hline $\mathrm{A}$ & $-15.15^{a}$ & $-22.01^{c}$ & $-15.92^{a b}$ & $-20.92 b c$ & $-17.13^{a b c}$ & 1.29 & $* * *$ \\
\hline B & $185.82^{b}$ & $197.70^{a b}$ & $238.02^{a}$ & $194.83^{\mathrm{ab}}$ & $222.00^{a b}$ & 11.10 & $* *$ \\
\hline $\mathrm{C}$ & $0.0348^{a}$ & $0.0314^{\mathrm{a}}$ & $0.0210^{b}$ & $0.0267^{a b}$ & $0.0209^{b}$ & 0.0021 & $* * *$ \\
\hline$a+b$ & $170.67^{b}$ & $175.69^{b}$ & $222.10^{\mathrm{a}}$ & $173.91^{b}$ & $204.88^{a b}$ & 11.22 & $* *$ \\
\hline $\mathrm{t}_{0}$ & $2.67^{b}$ & $3.42^{\mathrm{ab}}$ & $4.24^{\mathrm{a}}$ & $4.27^{\mathrm{a}}$ & $4.03^{\mathrm{a}}$ & 0.24 & $* * *$ \\
\hline
\end{tabular}

(1) IVDMD: in vitro dry matter degradability; IVOMD: in vitro organic matter degradability; GP: gas production; PF: partitioning factor. ${ }^{(2)}$ breeds_-goats: Saanen; sheep: Santa Inês; buffalo: Mediterranea; taurine cattle: Holstein; zebu cattle: Nelore. ${ }^{(3)}$ SEM: standard error of means. ${ }^{(4)}$ ns: not significant $(p>0.05) ;{ }^{*}: p \leq 0.05 ;{ }^{* *}: p \leq 0.01$; $* * *: p \leq 0.001$. (5) Model of Ørskov and McDonald (1979), modified by McDonald (1981): $p=a+b\left(1-\exp ^{-c t}\right)$, where $p=$ gas production $(\mathrm{mL})$, in time $t ; a$ and $b=$ constants of model; $c=$ production gas rate $\left(\mathrm{h}^{-1}\right) ; a+b=$ potential gas production $(\mathrm{mL}) ; t_{0}=\operatorname{lag}$ time $(\mathrm{h}) .{ }^{\mathrm{a}, \mathrm{b}, \mathrm{c}}$ means followed by distinct superscripts, within rows, are different (Tukey test at $5 \%$. 


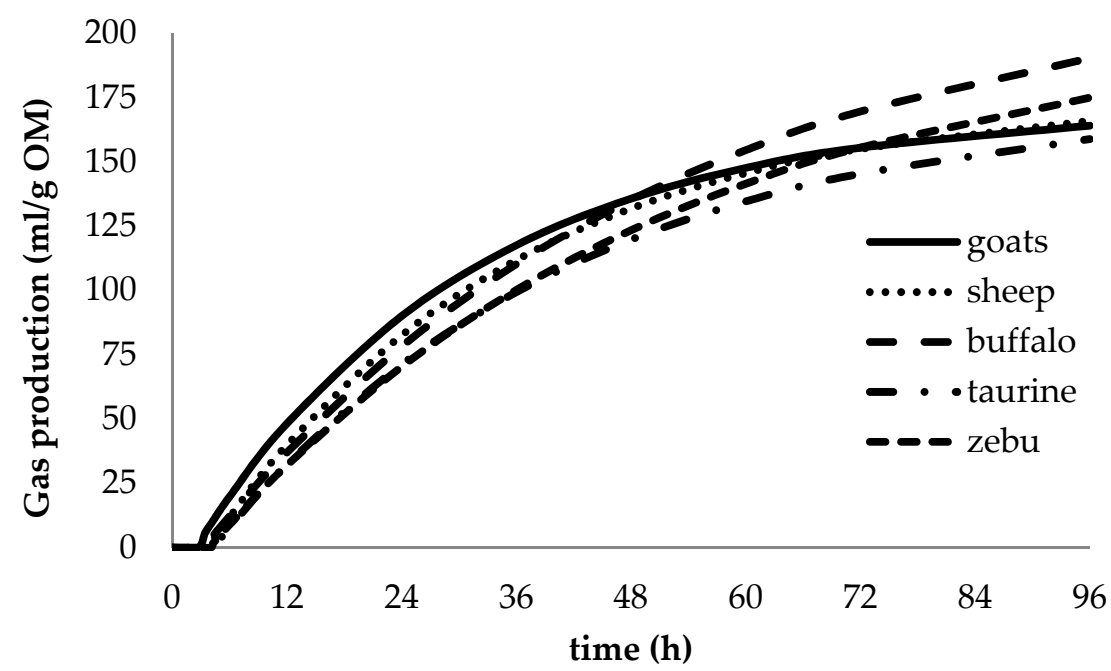

Figure 2. Effects of animal species on gas production profiles during in vitro rumen fermentation (pooled over condensed tannin treatments in four forages).

Table 5. Effect of animal species on short-chain fatty acids (SCFA) production evaluated during in vitro rumen fermentation.

\begin{tabular}{|c|c|c|c|c|c|c|c|}
\hline \multirow{2}{*}{ Variables } & \multicolumn{5}{|c|}{ Animal Species ${ }^{(1)}$} & \multirow{2}{*}{ SEM $^{(2)}$} & \multirow{2}{*}{$p$-Value ${ }^{(3)}$} \\
\hline & Goats & Sheep & Buffalo & Taurine Cattle & Zebu Cattle & & \\
\hline \multicolumn{8}{|l|}{$\begin{array}{l}\text { SCFA production } \\
\text { (mmol/g OMD) }\end{array}$} \\
\hline acetic acid & $3.37^{\mathrm{c}}$ & $3.92^{b c}$ & $5.44^{\mathrm{ab}}$ & $5.70^{\mathrm{a}}$ & $5.06^{\mathrm{ab}}$ & 0.41 & $* * *$ \\
\hline propionic acid & $1.30^{\mathrm{b}}$ & $1.45^{\mathrm{b}}$ & $2.25^{\mathrm{a}}$ & $2.28^{\mathrm{a}}$ & $2.11^{\mathrm{a}}$ & 0.14 & $* * *$ \\
\hline iso-butyric acid & $0.09^{a}$ & $0.06^{\mathrm{abc}}$ & $0.07^{\mathrm{ab}}$ & $0.02^{\mathrm{c}}$ & $0.04^{\mathrm{bc}}$ & 0.01 & $* * *$ \\
\hline butyric acid & $0.53^{c}$ & $0.61^{b c}$ & $0.90^{\mathrm{a}}$ & $0.88^{\mathrm{a}}$ & $0.82^{\mathrm{ab}}$ & 0.07 & $* * *$ \\
\hline iso-valeric acid & 0.10 & 0.10 & 0.10 & 0.12 & 0.10 & 0.01 & ns \\
\hline valeric acid & $0.12^{b c}$ & $0.10^{\mathrm{c}}$ & $0.15^{\mathrm{abc}}$ & $0.19^{\mathrm{a}}$ & $0.17^{a b}$ & 0.02 & $* * *$ \\
\hline total SCFA & $5.41^{\mathrm{c}}$ & $6.21^{b c}$ & $8.89^{a}$ & $9.17^{\mathrm{a}}$ & $8.30^{a b}$ & 0.61 & $* * *$ \\
\hline
\end{tabular}

(1) breeds—goats: Saanen; sheep: Santa Inês; buffalo: Mediterranean; taurine cattle: Holstein; zebu cattle: Nelore.

(2) SEM: standard error of means. ${ }^{(3)}$ ns: not significant $(p>0.05) ; *: p \leq 0.05 ;{ }^{* *}: p \leq 0.01 ;{ }^{* * *}: p \leq 0.001$. $^{\text {a,b,c }}$ means

followed by distinct superscripts, within rows, are different (Tukey test at $p \leq 0.05$ ).

\subsection{Interactions}

CT extract was effective $(p \leq 0.001)$ in reducing IVDMD and IVOMD in all four ruminant species evaluated (Figure 3). However, there were no differences in degradability among animal species between the paired treatment groups receiving CT and those which did not $(p>0.05)$. Among the treatment combinations including CT, buffalo and cattle showed greater microbial efficiency $(p \leq 0.01)$ than sheep or goats (Figure 3). The same was not observed for the partitioning factor by species not receiving CT because all species showed similar values. Condensed tannin addition to the diet increased the partitioning factor in large and small ruminant species.

The non-CT diet showed greater $(p \leq 0.001)$ levels of SCFA in cattle and buffalo than in sheep and goats. However, for animals receiving CT, there were no differences $(p>0.05)$ in SCFA between large and small ruminants (Figure 4). 

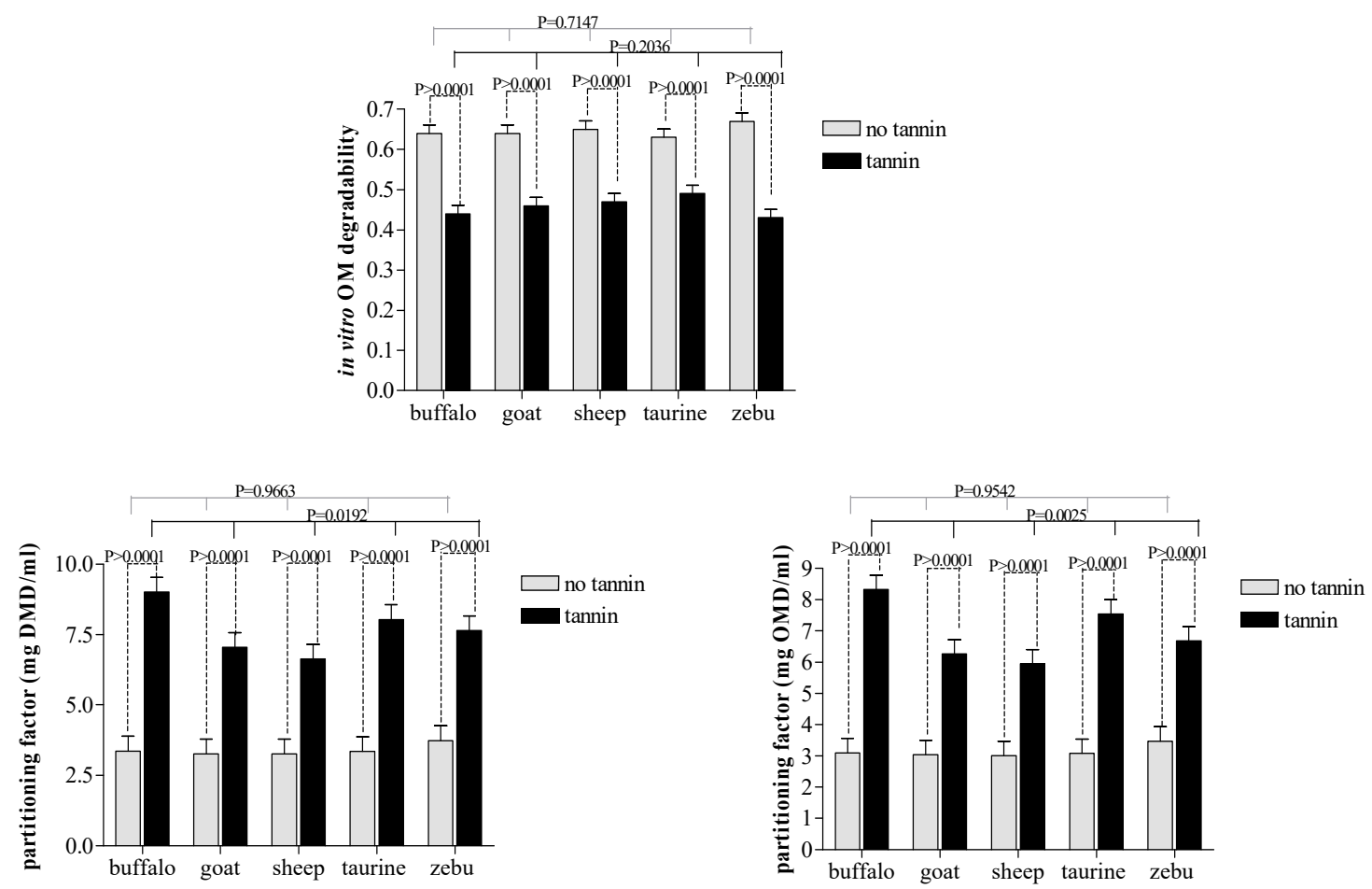

Figure 3. Effects of condensed tannin and animal species interactions on the organic matter degradability and partitioning factor during in vitro rumen fermentation.
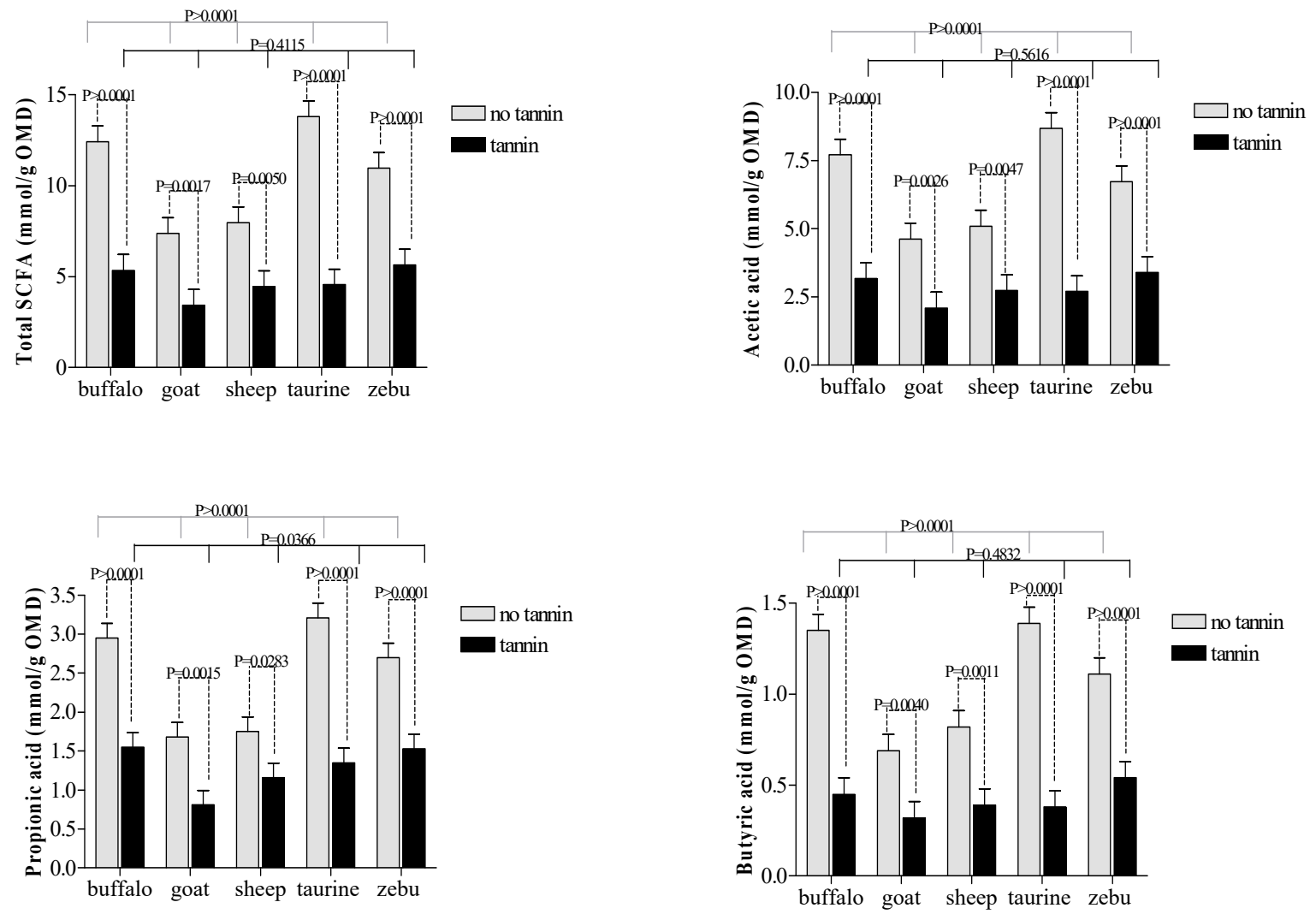

Figure 4. Effects of condensed tannin and animal species interaction on short-chain fatty acids (SCFA) production during in vitro rumen fermentation. 


\section{Discussion}

\subsection{Condensedtannin Extract Effects}

Flavonoids from Acacia spp. have potential biological effects on rumen fermentation [24]; thus, gas production reduction from diets containing CT extract was expected due to its effect on rumen microbiota. The regression equation for Acacia CT extract had a slow initial slope (12 h) followed by a slight increase, which allowed for a constant long-term assay up to $96 \mathrm{~h}$. The slow but steady gas production observed throughout the total incubation period reflects the lower ruminal digestion of organic matter in diets containing CT as reported elsewhere in the literature [25,26]. The inhibitory effects of CT on rumen gas production can be explained by a direct effect of CT-protein complexes on the rumen fibrolytic microbe and consequently lower cell wall degradation. The greater SCFA production and organic matter degradability for tannin-free diets also highlights the interference of CT on cell wall degradability. Previous in vitro studies support our findings that CT may reduce or slow organic matter degradability in the rumen, as reflected in less total SCFA production [27-29].

The addition of CT resulted in greater partitioning factors, expressed as mg OM degraded per $\mathrm{mL}$ of produced gases. The greater partitioning factor observed in this trial could be due to the initial washing losses by a substrate that might provide greater values of organic matter degradability in poorly substrate degradation samples with CT and therefore with less gas production. However, this assumption needs to be confirmed by future in vitro trials.

\subsection{Animal Species Effects}

Despite their different feeding behavior and digestive capacity, there were similar nutrient degradability and microbial efficiencies among ruminant species studied, which can be explained by the prolonged incubation period of $96 \mathrm{~h}$. The incubation duration used in our study may have allowed the adaptation of the rumen bacterial community to diets, eventually resulting in equivalent substrate fermentation. Contrary to our observations, Calabrò et al. [30] found differences in rumen fermentation between buffaloes and cattle; however, we believe that differences in microbial ecology and their donors probably are strongly reflected in short term incubation [31]. This emphasizes the importance of appropriate incubation duration in studies comparing substrates exposed to inoculants from donors fed different diets.

Due to better fiber digestion capacity, buffaloes, taurine and zebu cattle produced greater amounts of SCFA (per mmol MOD) than small ruminants, regardless of donor diet. Within the ruminant species, goats showed lower production of the major SCFA, including acetic, propionic and butyric acids as well as total SCFA. These results confirm the lower ruminal and omasal capacity and its less efficient degradability of poor quality forages by small-bodied browsers [2,3].

\subsection{Interactions}

The evolution of different feeding behaviors in ruminant species has required anatomic, physiologic and microbial gastrointestinal adaptations to their respective dietary niches [2,32]. In accordance with this hypothesis, Clauss et al. [33] reported clear effects of the ecology of wild ruminants on the dynamics of their protozoal fauna. In this context, the interaction between tanniniferous plants and browsers likely resulted in greater tolerance to flavonoid compounds than in grazers.

The major objective of our study was to assess possible CT-tolerant microbes present in rumen fluid from browsers or grazers. As a result, our 96-h incubation produced different results than those reported for $24 \mathrm{~h}$ by Bueno et al. [31], with CT addition resulting in similar total degradation of substrates in vitro during rumen fermentation among grazing and browsing ruminants. In other words, CT was effective in reducing cell wall degradability rates and SCFA production in all species evaluated. This finding suggests that an incubation time of $96 \mathrm{~h}$ was insufficient to alter rumen microbial dynamics associated with changing diets, resulting in an incomplete adaptation of ruminal microbial community to the new diet. 
Comparisons across CT treatment groups revealed greater propionic acid production and microbial efficiency in buffalo compared to cattle/taurine. Both results suggest that microbial populations in buffalo appear to be less sensitive to dietary CT. Although this contradicts most published research on the topic, it agrees with results reported by Salem [34] that buffalos were more tolerant of CT than other large grazers.

Despite the few differences observed as a result of our longer assay duration, results reported from in vivo animal trials must consider factors other than simply diet. These include anatomical adaptions of the mouth, teeth, salivary glands, body mass and digestive system altering selectivity, forage intake, passage rate and rumination time among the different feeding categories. As a result, degradability trials should account for differentiated rumen fermentation responses in browsers and grazers and selective versus bulk feeders when assaying CT-rich substrates.

\section{Conclusions}

The initial differences in the microbial communities resulting from feeding of donor species provide different responses between large and small ruminants in vitro tannin-rich diet fermentation. Inoculum from sheep and goats is less affected by the addition of CT than buffalo, zebu and taurine.

Author Contributions: Designed the study I.C.S.B.; performed the experiment and collected the samples, R.A.B. and I.C.S.B.; performed the laboratory analyses, G.M.F., G.B., and J.P.M.; analyzed and interpreted the data, G.M.F., R.A.B. and I.C.S.B.; wrote the manuscript: G.M.F. All authors have read and agreed to the published version of the manuscript.

Funding: Please add: This research was funded by Fundação de Amparo à Pesquisa do Estado de São Paulo (FAPESP), project number: 10/19654-2.

Acknowledgments: The authors acknowledge the financial support of Fundação de Amparo à Pesquisa do Estado de São Paulo (FAPESP), Cristina Teresa Alves (Embrapa, São Carlos, Brazil), Francisco Palma Rennó (FMVZ-Pirassununga, Brazil) and Paulo Henrique Mazza Rodrigues (FMVZ, Pirassununga, Brazil), who kindly collaborated with this study, and Seta ${ }^{\circledR}$ (Estância Velha, Brazil) for the CT extract.

Conflicts of Interest: The authors (I.C.S. Bueno, R. A. Brandi, G.M. Fagundes, G. Benetel, and J.P. Muir) have no financial or personal relationship with other people or organizations that could inappropriately influence or bias the research.

\section{References}

1. Fagundes, G.M.; Modesto, E.C.; Fonseca, C.E.M.; Lima, H.R.P.; Muir, J.P. Intake, digestibility and milk yield in goats fed Flemingia macrophylla with or without polyethylene glycol. Small Rumin. Res. 2014, 116, 88-93. [CrossRef]

2. Van Soest, P.J. Nutritional Ecology of the Ruminant, 2nd ed.; Cornell University Press: Ithaca, NY, USA, 1994; 476p.

3. Lamy, E.; Rawel, H.; Schweigert, F.J.; Capela e Silva, F.; Ferreira, A.; Costa, A.R.; Antunes, C.; Almeida, A.M.; Coelho, A.V.; Sales-Baptista, E. The effect of tannins on Mediterranean ruminant ingestive behavior: The role of the oral cavity. Molecules 2011, 16, 2766-2784. [CrossRef] [PubMed]

4. Muir, J.P. The multi-faceted role of condensed tannins in the goat ecosystem. Small Rumin. Res. 2011, 98, 115-120. [CrossRef]

5. Hofmann, R.R. Evolutionary steps of ecophysiological adaptation and diversification of ruminants: A comparative view of their digestive system. Oecologia 1989, 78, 443-457. [CrossRef] [PubMed]

6. Osawa, R.O.; Sly, L.I. Occurence of tannin-protein complex degrading Streptococcus sp. in feces of various animals. Syst. Appl. Microbiol. 1992, 15, 144-147. [CrossRef]

7. Odenyo, A.A.; McSweeney, C.S.; Palmer, B.; Negassa, D.; Osuji, P.O. In vitro screening of rumen fluid samples from indigenous African ruminants provides evidence for rumen fluid with superior capacities to digest tannin-rich fodders. Aust. J. Agric. Res. 1999, 50, 1147-1157. [CrossRef]

8. Jones, R.J.; Meyer, J.H.F.; Bechaz, F.M.; Stolzt, M.A.; Palmer, B.; van der Merwe, G. Comparison of rumen fluid from South African game species and from sheep to digest tanniniferous browse. Aust. J. Agric. Res. 2001, 52, 453-460. [CrossRef] 
9. Odenyo, A.A.; Bishop, R.; Asefa, G.; Jamnadass, R.; Odongo, D.; Osuji, P.O. Characterization of tannin-tolerant bacterial isolates from East African ruminants. Anaerobe 2001, 7, 5-156. [CrossRef]

10. Association of Official Analytical Chemists (AOAC). Official Methods of Analysis, 16th ed.; AOAC: Arlington, VA, USA, 1995.

11. Mertens, D.R. Gravimeric determination of amylase-treated neutral detergent fibre in feeds with refluxing beakers or crucibles: Collaborative study. J. Assoc. Off. Anal. Chem. 2002, 85, 1217-1240.

12. Makkar, H.P. Quantification of Tannins in Tree and Shrub Foliage: A Laboratory Manual; Springer: Berlin/Heidelberg, Germany, 2003.

13. Makkar, H.P.S.; Blümmel, M.; Borowy, N.K.; Becker, K. Gravimetric determination of tannins and their correlations with chemical and protein precipitation methods. J. Sci. Food Technol. 1993, 61, 161-165. [CrossRef]

14. Minho, A.P.; Bueno, I.C.S.; Louvandini, H.; Jackson, F.; Gennari, S.M.; Abdalla, A.L. Effect of Acacia molissima tannin extract on the control of gastrointestinal parasites in sheep. Anim. Feed Sci. Technol. 2008, 147, 172-181. [CrossRef]

15. Bueno, I.C.S.; Cabral Filho, S.L.S.; Gobbo, S.P.; Louvandini, H.; Vitti, D.M.S.S.; Aballa, A.L. Influence of inoculum source in a gas production method. Anim. Feed Sci. Technol. 2005, 123-124, 96-105. [CrossRef]

16. Theodorou, M.K.; Williams, B.A.; Dhanoa, M.S.; McAllan, A.B.; France, J. A simple gas production method using a pressure transducer to determine the fermentation kinetics of ruminant feeds. Anim. Feed Sci. Technol. 1994, 48, 185-197. [CrossRef]

17. Mauricio, R.M.; Mould, F.L.; Dhanoa, M.S.; Owen, E.; Channa, K.S.; Theodorou, M.K. A semi-automated in vitro gas production technnique for ruminant feedstuff evaluation. Anim. Feed Sci. Technol. 1999, 79, 321-330. [CrossRef]

18. Blümmel, M.; Makkar, H.P.S.; Becker, K. In vitro gas production: A technique revisited. J. Anim. Physiol. Anim. Nutr. 1997, 77, 24-34. [CrossRef]

19. Ørskov, E.R.; Mcdonald, I. The estimation of protein degradability in the rumen from incubation measurements weighted according to rate of passage. J. Am. Sci. 1979, 92, 449-453. [CrossRef]

20. Mcdonald, I. A revised model for estimation of protein degradability in the rumen. J. Agric. Sci. 1981, 96, 251-252. [CrossRef]

21. Erwin, E.S.; Marco, G.J.; Emery, E.M. Volatile fatty acid analyses of blood and rumen fluid by gas chromatography. J. Dairy Sci. 1961, 44, 1768-1771. [CrossRef]

22. Getachew, G.; Makkar, H.P.S.; Becker, K. Tropical browses: Contents of phenolic compounds, in vitro gas production and stoichiometric relationship between short chain fatty acid and in vitro gas production. J. Agric. Sci. 2002, 139, 341-352. [CrossRef]

23. SAS INSTITUTE. The SAS System for Windows; Release 8.01; Sas Institute: Cary, NC, USA, 2000.

24. Bueno, I.C.S.; Vitti, D.M.; Louvandini, H.; Abdalla, A.L. A new approach for in vitro bioassay to measure tannin biological effects based on a gas production technique. Anim. Feed Sci. Technol. 2008, 141, 153-170. [CrossRef]

25. Patra, A.K.; Saxena, J. Exploitation of dietary tannins to improve rumen metabolism and ruminant nutrition. J. Sci. Food Agric. 2011, 9, 24-37. [CrossRef]

26. Tedeschi, L.O.; Ramírez-Restrepo, C.A.; Muir, J.P. Developing a conceptual model of possible benefits of condensed tannins for ruminant production. Animal 2014, 8, 1095-1105. [CrossRef] [PubMed]

27. Hervás, G.; Frutos, P.; Serrano, E.; Mantecón, A.R.; Giráldez, F.J. Effect of tannic acid on rumen degradation and intestinal digestion of treated soya bean meals in sheep. J. Agric. Sci. 2000, 135, 305-310.

28. Tiemann, T.T.; Lascano, C.E.; Wettstein, H.R.; Mayer, A.C.; Kreuzer, M.; Hess, H.D. Effect of the tropical tannin-rich shrub legumes Calliandra calothyrsus and Flemingia macrophylla on methane emission and nitrogen and energy balance in growing lambs. Animal 2008, 2, 790-799. [CrossRef] [PubMed]

29. Hariadi, B.T.; Santoso, B. Evaluation of tropical plants containing tannin on in vitro methanogenesis and fermentation parameters using rumen fluid. J. Sci. Food Agric. 2010, 90, 456-461. [PubMed]

30. Calabrò, S.; Moniello, G.; Piccolo, V.; Bovera, F.; Infascelli, F.; Tudisco, R.; Cutrignelli, M.I. Rumen fermentation and degradability in buffalo and cattle using the in vitro gas production technique. J. Anim. Physiol. Anim. Nutr. 2008, 92, 356-362. 
31. Bueno, I.C.; Brandi, R.A.; Franzolin, R.; Benetel, G.; Fagundes, G.M.; Abdalla, A.L.; Louvandini, H.; Muir, J.P. In vitro methane production and tolerance to condensed tannins in five ruminant species. Anim. Feed Sci. Technol. 2015, 205, 1-9. [CrossRef]

32. Gordon, I.J. Browsing and grazing ruminants: Are they different beasts? Forest. Ecol. Manag. 2003, 181, 13-21. [CrossRef]

33. Clauss, M.; Müller, K.; Fickel, J.; Streich, W.J.; Hatt, J.-M.; Südekum, K.-H. Macroecology of the host determines microecology of endobionts: Protozoal faunas vary with wild ruminant feeding type and body mass. J. Zool. 2011, 283, 169-185. [CrossRef]

34. Salem, A.F.Z. Impact of season of harvest on in vitro gas production and dry matter degradability of Acacia saligna leaves with inoculum from three ruminant species. Anim. Feed Sci. Technol. 2005, 123, 67-79. [CrossRef]

(C) 2020 by the authors. Licensee MDPI, Basel, Switzerland. This article is an open access article distributed under the terms and conditions of the Creative Commons Attribution (CC BY) license (http://creativecommons.org/licenses/by/4.0/). 